\title{
Hybrid Warfare and the Changing Character of Conflict
}

\section{Bastian Giegerich}

International Institute for Strategic Studies (IISS), London, http://www.iiss.org

\begin{abstract}
The idea that international conflict might be seeing more hybrid warfare and hybrid threats has animated debate among security and defense establishments in the run-up to NATO's 2016 Warsaw Summit. While the Alliance has located the issue of hybrid war in the specific context of the Russia/Ukraine crisis and in 2014 triggered efforts to prepare NATO to effectively meet hybrid warfare threats, the scope of the challenge is much wider and the core dynamics are often located outside of the military realm. The article reviews the recent conceptual debates about hybrid warfare, suggesting that hybrid conflicts defy our attempts to press them into known categories and locate them clearly on a spectrum of war and peace. NATO Member States will have to invest in resilience and conventional deterrence to counter hybrid threats.
\end{abstract}

Keywords: hybrid threats; conflict; resilience; deterrence; strategy.

From "little green men" in Crimea to "little blue men" in the South China Sea, the idea that international conflict might be seeing more hybrid warfare and hybrid threats has animated debate among security and defense establishments in NATO and beyond. ${ }^{1}$ In fact, the term hybrid warfare has become a bit of a staple of Europe's security policy vocabulary. NATO and the EU are working on strategy papers aimed at strengthening defensive capabilities and preventing hybrid attacks. National governments drafting security and defense review documents make frequent reference to the need to address hybrid threats. Journalists have adopted the term "hybrid war" as a shorthand for Russian tac-

1 Both terms refer to unbadged personnel, see: Vitaly Shevchenko, “'Little Green Men' or 'Russian invaders'?" BBC News, 11 March 2014; Christopher Cavas, "China's 'Little Blue Men' Take Navy's Place in Disputes," Defense News, 2 November 2015. 
tics in Ukraine, apparently with the assumption that readers already know what this means.

NATO's Wales Summit Declaration from 5 September 2014 says Alliance leaders "will ensure that NATO is able to effectively address the specific challenges posed by hybrid warfare threats, where a wide range of overt and covert military, paramilitary, and civilian measures are employed in a highly integrated design. It is essential that the Alliance possesses the necessary tools and procedures required to deter and respond effectively to hybrid warfare threats, and the capabilities to reinforce national forces." 2

While the Wales declaration put the issue of hybrid war in the specific context of the Russia/Ukraine crisis and triggered efforts to prepare NATO to effectively meet such threats, the scope of the challenge is much wider and the core dynamics are often located outside the military realm. Earlier work conducted at NATO Allied Command Transformation under the label "Countering Hybrid Threats" acknowledges as much, but it seems as if the insights generated at the time were not systematically pursued until Russia's illegal annexation of Crimea served as a stark reminder. ${ }^{3}$

\section{Why Should We Care?}

With a view to the conflict in Ukraine, analysts come to different assessments. Anton Dengg and Michael Schurian argue the Ukraine conflict suggests employing hybrid means to project power might be an important trend that could shape the character of threats to come. ${ }^{4}$ The British National Security Strategy and its supporting Strategic Defence and Security Review, published at the end of November 2015, state that "the illegal annexation of Crimea in 2014 and continuing support for separatists in eastern Ukraine through the use of deniable, hybrid tactics and media manipulation have shown Russia's willingness to undermine wider international standards of cooperation in order to secure its perceived interest." ${ }^{5}$ These strategic documents treat hybrid threats both as tier one challenges, which might affect the UK directly, and as tier two threats, which would start as a hybrid attack on an ally. Diego Ruiz Palmer summarizes Russia's aims as achieving "politically decisive outcomes with, if possible, no or

2 NATO, "Wales Summit Declaration Issued by the Heads of State and Government participating in the meeting of the North Atlantic Council in Wales," 5 September 2014, http://www.nato.int/cps/en/natohq/official_texts_112964.htm (accessed 11 December 2015).

3 For a summary of the ACT work, see Michael Miklaucic, "NATO Countering the Hybrid Threat," 23 September 2011, http://www.act.nato.int/nato-countering-thehybrid-threat (accessed 11 December 2015).

4 Anton Dengg and Michael Schurian, Zum Begriff der Hybriden Bedrohungen, in Vernetzte Unsicherheit - Hybride Bedrohungen im 21. Jahrhundert, ed. A. Dengg and M. Schurian (Vienna: Landesverteidigungsakademie, 2015), 23-75.

5 HM Government, National Security Strategy and Strategic Defence and Security Review 2015. A Secure and Prosperous United Kingdom, November 2015, Cm 9161, at 18. 
only a limited and overt use of military force, while being prepared to act militarily, with devastating effect at the operational level... aim at attaining a decisive political advantage short of war." ${ }^{6}$ The main takeaway is that much of the activity related to hybrid conflict will take place beneath the threshold that most Western observers would consider armed conflict, much less war.

Samuel Charap at the International Institute for Strategic Studies suggests that Russia's approach would not travel well beyond the specific circumstances of the conflict in Ukraine. Charap maintains Russia does not have "a hybrid-war doctrine that could be effectively deployed against NATO" and goes on to warn talking up the issue of hybrid warfare poses a danger in itself: "Russian strategists believe that the US is willing to risk conducting a limited, hybrid operation in Russia ... just as NATO strategists believe Russia is willing to risk the same on the territory of [NATO]." 7 Can Kasapoglu, in a rather nuanced analysis, points out that NATO might not be facing a new Russian military strategy, but the Alliance should realize that "new military thinking that brings about shifts at strategic, operational, and tactical levels along with doctrinal order of battle and military strategic culture" has emerged in Russia around the concept of nonlinear warfare. ${ }^{8}$ Lawrence Freedman offers yet another perspective, submitting that Russia may well have conducted hybrid warfare in Ukraine, but was actually not very successful and the advantages offered to the attacker by hybrid means are exaggerated. ${ }^{9}$

Aside from the question of whether Russian behavior in Ukraine is a model for hybrid warfare and, if so, how far can it be generalized and was successful, another core debate rages around the issue of the appropriateness of the label itself. To some observers the current preoccupation with hybrid warfare is a fad at best, and represents intellectual laziness at worst. Proponents of the former view would insist that we are not actually witnessing anything new, but merely a modern-day interpretation of the time-honored combination of conventional and unconventional approaches. Supporters of the latter view might argue that hybrid warfare has become a convenient label to file away all the issues we currently do not understand about the changing character of conflict. Overall, however, while its nature and importance might well be contested, ignoring the evolution of a hybrid approach to conflict would come at the Alliance's peril.

Frank Hoffman's writing is a good analytical starting point to clarify the concept, not least because Hoffman was among the writers who coined the term in its current incarnation. He stresses that hybrid threats amount to much more

6 Diego A. Ruiz Palmer, "Back to the Future? Russia's Hybrid Warfare, Revolutions in Military Affairs, and Cold War Comparisons," Research Paper No. 120 (NATO Defense College, October 2015), 2.

7 Samuel Charap, "The Ghost of Hybrid War," Survival 57:6 (2015): 53, 57.

8 Can Kasapoglu, "Russia's Renewed Military Thinking: Non-Linear Warfare and Reflexive Control," Research Paper No.121 (NATO Defense College, November 2015), 11.

9 Lawrence Freedman, "Ukraine and the Art of Limited War," Survival 56:6 (2014): 738. 
than simple combinations of a variety of actors, tactics and approaches. Hybrid challengers fuse different modes of conflict and it is that new synthesis that emerges that is difficult to deal with, because it confounds Western binary conceptions of peace and war, of military and non-military means, and of conventional and irregular approaches. ${ }^{10}$ Commenting recently on the matter, Hoffman said Western actors "think of things in black-and-white terms" and still need to improve significantly at understanding conflict in the spaces in between, in the grey areas. ${ }^{11}$ Given that a fusion of conflict patterns, which had previously been seen as unconnected, is the core of hybrid threats, it logically follows that hybrid threats and hybrid warfare will come in many guises - this challenge will continue to evolve.

One does not have to subscribe to a whole new hybrid paradigm to acknowledge that hybrid warfare and hybrid threats currently do affect European security directly and also can serve as a useful construct to think through the capabilities to prevent and counter certain contemporary challenges. In itself, the combination of regular and irregular forces in one theater of operations is of course quite a conventional strategy. ${ }^{12}$ What is new, however, is the immediate relevance to Europe's security today. Hybrid actors in the East and South are directly threatening European security interests, and even appear to be calling the entire Euro-Atlantic security order into question. Vladimir Putin's great power ambitions are incompatible with the principles and value structure of European security institutions. Yet with regard to the Russian government, the established methods of international relations, including their military dimensions, should still be effective. On the other hand, the caliphate of Abu Bakr al-Baghdadi, the barbarity and nihilistic contempt for humanity of the socalled Islamic State (IS), makes a negotiated solution with this actor seem unlikely, if not plain absurd. Both are hybrid challengers.

Hybrid wars have therefore reached Europe from two directions, and in very different form. In the East is a state actor, Russia under Putin, who deliberately uses non-state means, and in the South is a non-state actor, Islamic State (IS), whose leaders are attempting to establish structures that are at least similar to those of a state, and who also have access to means of violence that ordinarily

10 Frank G. Hoffman, Conflict in the $21^{\text {st }}$ Century: The Rise of Hybrid Wars (Arlington, VA: Potomac Institute for Policy Studies, 2007), at www.potomacinstitute.org/ images/stories/publications/potomac_hybridwar_0108.pdf (accessed 11 December 2015); James N. Mattis and Frank G. Hoffman, "Future Warfare: The Rise of Hybrid Wars," Proceedings Magazine, 132:11 (2005), http://milnewstbay.pbworks.com/f/ MattisFourBlockWarUSNINov2005.pdf (accessed 11 December 2015).

11 Quoted in Thomas Gibbons-Neff, "The 'new' type of war that finally has the Pentagon's attention," Washington Post, 3 July 2015, https://www.washingtonpost.com/ world/national-security/the-new-type-of-war-that-finally-has-the-pentagonsattention/2015/07/03/b5e3fcda-20be-11e5-84d5-eb37ee8eaa61_story.html

(accessed 11 December 2015).

12 Max Boot, "Countering Hybrid Warfare," in Armed Conflict Survey 2015 (Abingdon: International Institute for Strategic Studies, 2015), 11-20. 
tend to be afforded to states, or more precisely to their armed forces. These enemies of Europe are hybrid entities in the sense that they are able to use all available instruments of power in a theater of operations in a coordinated way, and with at least a certain degree of central control. At the same time, they pursue the same goals that have always motivated actors in armed conflicts: gaining a psychological and physical advantage. In this struggle, hybrid warfare is no different from other forms of war.

\section{Implications of the Hybrid Approach to Conflict and Policy Recom- mendations}

As has been suggested, the implications of a hybrid approach to conflict are wide-ranging and cut across concepts, material capability aspects, legal matters, and institutional innovation. ${ }^{13}$ Hybrid conflict defies the attempt to press it into known categories. It is not simply in-between state-driven conflict and non-state-driven conflict, as the recent US military strategy suggests. ${ }^{14}$ That particular strategic document does have the advantage, though, of thinking about conflict in terms of a continuum, rather than suggesting distinct conditions such as war and peace. Hybrid conflict takes place in the intermediate spaces, or at the seams of traditional ways of thinking.

On the response side, the key conceptual innovation has been the discovery, or perhaps the rediscovery, of resilience as the underpinning principle of security policy. Resilience in the context of national security refers to the ability of societies to manage threats and risks, to adapt to them, and to recover from them should an attack or event occur, without losing the ability to provide basic functions and services to the members of that society. ${ }^{15}$ In short, it is the capacity to degrade gracefully under pressure and then bounce back. Resilience is foremost a matter of reducing one's own vulnerabilities. Given that doing so makes it less likely that hybrid attackers manage to achieve their intended goals, resilience also contributes to deterrence in a hybrid context by reducing the potential gains any attacker might hope to reap.

If hybrid war is the evil twin of NATO's comprehensive approach, an implication is actually that NATO will have to redouble its efforts to make the comprehensive approach more successful and in particular strengthen the links with other organizations. It is clear that even deciding on responsibilities at the national level and task-sharing between NATO, the EU, and other organizations will be anything but easy. Preventing and defending against hybrid threats will need to involve the entire government on the national and local level, the pri-

13 Patryk Pawlak, "Understanding Hybrid Threats," European Parliamentary Research Service (EPRS), 24 June 2015.

14 US Joint Chiefs of Staff, The National Military Strategy of the United States of America 2015 (Washington, DC: DOD, 2015), 4.

15 Oliver Tamminga, "Zum Umgang mit hybriden Bedrohungen. Auf dem Weg zu einer nationalen Resilienzstrategie," SWP-Aktuell 92 (2015): 3. 
vate sector, and arguably society as a whole. The synergies of the networked approach, so straightforward in theory, are hard to achieve in practice. There is no single responsibility for defense against hybrid threats and therefore no obvious center of decision-making. The spectrum is wide, and systematically checking which organization and body would be in charge of each element of a response to a hybrid attack will produce a picture that makes it only too clear that at the national level, and international level, the available instruments are insufficiently interconnected. As Christian Mölling has argued, a hybrid security policy is the appropriate answer to hybrid threats in order to meet "adversaries in the non-military arena to prevent an escalation toward military force." ${ }^{16}$

For NATO, many material and capability-related implications are currently derived from the hypothetical risk "of Russia being tempted to coerce or undertake limited aggression against an Ally in the expectation that it might not elicit a NATO response." ${ }^{17}$ It is not necessary to believe that this is actually a likely course of action for Russia: even the perception, certainly shared by some of the allies, that it could be a viable strategy for Russia is hugely destabilizing. NATO will therefore have to go much farther on its path to military adaption and reassurance. If in 2015 it was noted that Trident Juncture was NATO's biggest exercise in a decade, the following years might bring a requirement to exercise at a much higher level as far as the number of contributing troops is concerned. NATO headquarters used to be full of officers capable of planning and implementing multinational troop movements at the corps level and above. Today, those skills and experience are partly lost and will need to be rebuilt, just as decision-making structures and bureaucratic procedures need to be streamlined and adjusted to the fact that significant international movements of personnel and materiel might have to occur in crisis situations that do not correspond to a legal state of war.

There is also a need for action in the area of conventional military deterrence. This includes the permanent stationing of significant NATO forces in the territory of at-risk member states, ideally in the form of multinational units. The deterrence strategy should not be based exclusively on the assumption that in the event of a crisis, NATO will immediately be able to quickly and easily strengthen its forces. NATO member states have also begun to build specialized military formations to support defense against hybrid attack and deal with hybrid conflict elsewhere. A prominent example is the British $77^{\text {th }}$ Brigade, a combined Regular Army and Army Reserve unit. Recently formed, the $77^{\text {th }}$ Brigade focuses on intelligence, surveillance, and reconnaissance. It is designed to conduct modern information operations, particularly to counter hybrid warfare.

It should be a priority to systematically identify vulnerabilities to hybrid threats so that the currently much-vaunted resilience can be strengthened.

${ }^{16}$ Christian Mölling, "From Hybrid Threats to Hybrid Security Policy," Ethics and Armed Forces 2 (2015): 2.

17 Ruiz Palmer, "Back to the Future," 10. 
This may include marginalized groups in society, who may be targets for radicalization efforts or ideological mobilization. It may be a case of energy dependencies that can be turned into means of exerting political pressure. Serious investment is needed in the area of intelligence analysis, security foresight, and weak signals. Another important area of action for defense against hybrid threats is early warning, and to produce a situation assessment that is appropriate for the character of this form of conflict. Here it will be necessary to share and evaluate findings and results of national intelligence service work more rapidly in the international framework within the EU and NATO than is currently the case. Even weak signals pointing to a hybrid attack may consolidate into a pattern if coordination of this kind takes place.

Building up capability in this area will enable NATO to better understand the hybrid threat phenomenon, develop metrics to get a grip on events, systematically address vulnerabilities, and contemplate how hybrid threats might develop in the future. NATO currently lacks the funding mechanisms to take advantage of open-source information that could be provided by think tanks and expert analysts. NATO's public diplomacy budget is spent on events that may or may not have analytical value. NATO ACT has an academic outreach program, but its activities seem better at forming and maintaining networks than using agile partnerships to insert external analysis in NATO processes as and when needed.

Information operations are an integral part of hybrid warfare used to form narratives and, generally, to influence political opinion-making among the target population. Strategic communication offers an opportunity to counteract this, but only if it is coherent, consistent, fast, and precise. While this is certainly not a simple feat, it is surprising to see how difficult NATO and EU seem to find even basic coordination. For example, on 22 June 2015 the EU adopted the Action Plan on Strategic Communication. Back in July 2014, NATO set up the Strategic Communications Centre of Excellence in Latvia for the same purpose. The EU action plan makes no reference to this, while the work plan for 2015 on the NATO center's website does not indicate any prioritization of cooperation with the EU. ${ }^{18}$ Meanwhile, however, both organizations have stated that close coordination is needed in precisely this area. With a challenge that confounds traditional categories of analysis, decision-makers and experts alike will need to be creative. The point is not that an event like the invasion of Crimea necessarily forms a template for future conflict, but that the principles on which they were based will inform the next challenger and hybridity as an underlying factor in conflict is here to stay.

18 European Union, "Action Plan on Strategic Communication," Ref. Ares(2015)2608242, 22 June 2015, http://eap-csf.eu/assets/files/Action\%20PLan.pdf (accessed 31 October 2015); NATO Strategic Communications Centre of Excellence, http://www.stratcomcoe.org/about-us (accessed 31 October 2015). 


\section{About the author}

Dr. Bastian Giegerich is Director of Defence and Military Analysis at The International Institute for Strategic Studies (IISS) in London. He is a contributor to the IISS's Military Balance and Strategic Survey. From 2010 until 2015, Bastian worked for the German Ministry of Defense, both in research and policy roles, while also serving as the IISS Consulting Senior Fellow for European Security. He holds a MA in Political Science from the University of Potsdam and a PhD in International Relations from the London School of Economics. Bastian is the author and editor of several books on European security and defense matters. His articles have appeared in journals such as Survival, Security Studies and International Politics, among others, as well as in various print media outlets. Bastian has taught International Relations, Military Studies, and Public Administration courses at the London School of Economics, the University of Potsdam, and the University of Kassel.E-mail: Giegerich@iiss.org. 